\title{
Field studies evaluate methods to prevent sudden oak death in oaks and tanoak
}

Tedmund J. Swiecki and Elizabeth A. Bernhardt, Phytosphere Research, 2017 Davis St., Vacaville, CA 95687. Corresponding author: phytosphere@phytosphere.com

\begin{abstract}
We conducted field studies to evaluate management methods for the prevention of sudden oak death (SOD), caused by Phytophthora ramorum. Phosphite was applied as a trunk spray at the product label rate $\left(22.36 \%\right.$ a.i. aqueous solution + Pentra-Bark ${ }^{\circledR}$ surfactant at $\left.2.3 \% \mathrm{v} / \mathrm{v}\right)$ to a 1.35 ha block of 233 largediameter (mean $46 \mathrm{~cm}$ ) tanoaks. Annual phosphite applications began in 2008; symptoms of $P$. ramorum were not seen in the stand until 2011. In 2013, SOD incidence in treated trees was 32\% compared to $18 \%$ in adjacent untreated trees. Subsequent discontinuation of phosphite treatment did not affect disease progress; SOD continued to increase at similar rates in phosphite-treated and control trees, reaching 47\% among phosphite-treated trunks compared to $32 \%$ in untreated trunks. Preventative phosphite application did not delay SOD onset, or reduce SOD incidence or SOD-related mortality.

In contrast, in other studies we found that removal of California bay (Umbellularia californica) around coast live oaks (Quercus agrifolia), California black oaks (Q. kelloggii), and Shreve oaks (Q. parvula var. shrevei) strongly decreased or prevented new disease development over study periods ranging from 5 to 7 years. In these studies, SOD incidence in oaks treated by removal of nearby California bay was 20 to $25 \%$ lower than in untreated controls.
\end{abstract}

\section{Introduction}

Since its introduction into California in the mid-1990s, Phytophthora ramorum Werres, de Cock \& Man in't Veld is estimated to have killed millions of trees (Cunniffe et al. 2016). In California forests, $P$. ramorum functions primarily as an aerial pathogen, sporulating on leaves or twigs of various hosts, but causing lethal bole infections only on a few species, including tanoak (Notholithocarpus densiflorus [Hook. \& Arn.] P.S. Manos, C.H. Cannon, \& S. Oh), coast live oak (Quercus agrifolia Née), California black oak (Q. kelloggii Newb.), canyon live oak (Q. chrysolepis Liebm.), and Shreve oak (Q. parvula var. shrevei (C.H. Mull.) Nixon) (Rizzo et al. 2002, Swiecki et al. 2016).

In general, tanoak is more susceptible to P. ramorum than are the oak hosts (Rizzo et al. 2002, Swiecki and Bernhardt 2013). Phytophthora ramorum sporulates readily on tanoak twig cankers (Davidson et al. 2008). Sporangia and zoospores can be dispersed by windblown rain to other parts of the canopy, initiating additional leaf and twig infections. Spores can also be splashed from infected tanoak twigs to canopies of adjacent tanoaks, so P. ramorum can readily spread between trees in a tanoak stand. The search for control methods began as soon as sudden oak death (SOD) was recognized as a new disease (Swiecki and Bernhardt 2016). Preventing infection by treating trunks of susceptible trees with potassium phosphite as a spray application was identified as a possible chemical control method (Garbelotto et al. 2007, Garbelotto and Schmidt 2009). Various assays have shown that phosphite can reduce the rate of $P$. ramorum lesion expansion in treated trees (Garbelotto et al. 2007, Garbelotto and Schmidt 2009).

Potassium phosphite (also known as potassium phosphonate, or mono- and di-potassium salts of phosphorous acid) is a selective, systemic chemical that has been used to manage Phytophthora diseases, particularly root rot caused by Phytophthora cinnamomi Rands (Guest and Grant 1991). The exact 
mechanism by which phosphite controls Phytophthora is not fully understood. Concentrations in a plant may be high enough to be directly toxic to Phytophthora in some cases. At lower concentrations, phosphite stimulates the plant to mount a resistance reaction in response to infection (Guest and Grant 1991, Hardy et al. 2001). Phosphites have a high level of environmental safety and very low nontarget toxicity. EPA classifies phosphites as biopesticides because these salts are closely related to common, widely occurring substances (USEPA 1998).

Although potassium phosphite pesticides (e.g., Reliant ${ }^{\circledR}$, Agri-Fos $^{\circledR}$ ) list bark spray application for control of $P$. ramorum on the label, no large-scale field tests of this treatment in tanoak had been conducted before our study was initiated. Because trunk spray applications of potassium phosphite to large numbers of trees entails substantial ongoing cost and effort, the treatment is most likely to be used to protect highvalue trees or stands from SOD. Furthermore, treatment efficacy needs to be high to justify its recurring costs for repeated applications. An effective treatment would maintain the number of SOD killed trees to a low level indefinitely (minimize the final size of the outbreak) and delay onset of SOD in a population that is exposed to $P$. ramorum inoculum.

Phosphite application to tanoak could prevent disease by one or both of the following mechanisms: (1) suppressing foliar and twig infections to reduce local inoculum production and (2) increasing the tree's resistance to bole infections. If the first mechanism is important, efficacy of phosphite should be maximized by treating all tanoaks in a large contiguous area, because the proportion of treated trees surrounded by other treated trees will increase as plot size increases. Treatment of individual trees, or plots that are only a few tanoak canopies across, are unlikely to allow for optimum expression of reduced inoculum effects because inoculum from adjacent and nearby non-treated trees could be splashed and blown onto treated trees.

To maximize the potential reduction in local inoculum production, all phosphite-treated trees in this study were in a large (1.35 ha) contiguous area in which a high proportion of all treated trees were adjacent to other treated trees. In addition, phosphite treatments were initiated well before the tanoak population was exposed to P. ramorum inoculum. Nontreated tanoaks located beyond the perimeter of the phosphitetreated population served as controls and were monitored to assess when P. ramorum infections appeared and how the spatial distribution of SOD developed across the study area over time. By monitoring a large population of trees in a contiguous area over a long period of time, it is possible to detect a strong treatment effect after the area has been invaded by $P$. ramorum.

In contrast to tanoak, SOD infection among susceptible oak species in California is largely a byproduct of the P. ramorum foliar disease cycle on California bay (Umbellularia californica Hook. \& Arn). When conditions are favorable for foliar disease development in California bay, large numbers of spores from infected leaves are dispersed to nearby oaks by dripping and splashing water. SOD incidence, severity, and mortality rates increase as the distance from oak trunk to California bay foliage decreases (Swiecki and Bernhardt 2002, 2008). Coast live oaks with California bay foliage directly over or within $1.5 \mathrm{~m}$ of the trunk have the highest risk of infection and mortality. Disease risk also increases as the total amount of California bay cover within 2.5 to $5 \mathrm{~m}$ of the oak trunk increases (Swiecki and Bernhardt 2008). Foresters have long manipulated stands to favor one species over another. From the spatial relationship between California bay and SOD in susceptible oak species, we inferred that removing California bay from the vicinity of susceptible oak trees should lessen disease pressure and provide a means for controlling disease. Disease in tanoak is also greatly increased in the presence of California bay (Davidson et al. 2005), but the fact that $P$. ramorum causes sporulating foliar and twig infections in tanoak rules out California bay removal as an effective long-term means of preventing SOD in tanoak.

We investigated whether removing California bay would lower SOD incidence in three separate studies in northern California. California bay removal can be implemented at various scales (Swiecki and Bernhardt 
2013). Area-wide removal of California bay from entire stands of oaks is likely to reduce inoculum near oaks to the greatest degree and should be the most effective treatment for preventing SOD development and mortality in susceptible oak species. This approach was tested in two locations, on stands of coast live oak and Shreve oak, respectively. Where this approach is not feasible or desirable, lesser levels of bay removal may still be beneficial, including localized removal of California bay around individual oaks. In the third oak study, we tested whether localized California bay removal around individual coast live oak and California black oak can prevent SOD.

\section{Methods}

\section{Study design}

In these field studies, exposure of subject trees to P. ramorum inoculum could not be controlled and timing of exposure to inoculum could not be predicted. Infection is typically nonuniform over various spatial scales. We therefore utilized a prospective cohort study design to assess possible treatment effects. For both tanoaks and oaks, we identified populations of host trees that were uniform to the degree possible with respect to potential for exposure to inoculum, environmental parameters, and factors known or likely to be related to disease risk and followed these populations for extended periods after the start of treatments to observe disease outcomes. Disease status was assessed before treatments were applied.

Prior to applying bay-removal treatments in the oak studies, both control and treated trees selected for monitoring were rated as being at moderate to high risk of $P$. ramorum infection. SOD risk assessment for oaks was based on proximity to bay and oak-related risk factors. Tanoaks throughout the study area were considered to have a uniformly high SOD risk.

\section{Potassium phosphite trunk spray application to tanoak}

The study location is on San Francisco Public Utilities Commission (SFPUC) Peninsula Watershed lands on a ridge southwest of Crystal Springs Reservoir (San Mateo County). The study area is on a flat ridge $10 \mathrm{~km}$ west of the Pacific Ocean where summer fog intrusion is common. Resource managers identified a unique, high-value stand of mostly large-diameter tanoaks (range $6.5 \mathrm{~cm}$ to $93 \mathrm{~cm}$, mean $46 \mathrm{~cm}$ ), most of which were at least $30 \mathrm{~m}$ tall, with long, clear trunks. The tanoaks were intermixed with large second growth coast redwoods (Sequoia sempervirens (D. Don) Endl.) and some madrone (Arbutus menziesii Pursh). The stand appears to have developed after the area was logged in the late $19^{\text {th }}$ or early $20^{\text {th }}$ century. Canopy cover was nearly complete at the study start.

The entire study area was similar in stand composition and structure and topographic position. No a priori factors were identified to indicate that SOD risk would vary across the study area. The treated trees were within a roughly rectangular area, about $170 \mathrm{~m}$ long and 60 to $100 \mathrm{~m}$ wide (about 1.35 ha total) that included 233 tanoak trunks from both single- and multi-trunked trees (average tanoak density 173 trunks/ha). Control trees were monitored in four areas, each on a different side of the area containing treated trees. We monitored about 60 trunks in each control area, which were separated from the treated trees by a buffer of at least two tree canopy widths. The four control areas (1.37 ha in aggregate) contained a total of 243 monitored trunks (average tanoak density 177 trunks/ha). A single small (DBH about $12 \mathrm{~cm}$ ) California bay with no P. ramorum foliar symptoms located within the phosphite treated area was removed prior to the start of the study. No other California bay were located within at least 100 $\mathrm{m}$ of the study area. No evidence of SOD was observed within $1 \mathrm{~km}$ of the stand, but SOD-killed coast live oaks were present $2.5 \mathrm{~km}$ east of the stand. Some scattered tanoak mortality seen in the study area was related to root disease, mostly associated with Armillaria gallica Marxm. \& Romagn.

Tree observations and data - At the start of the study, numbered aluminum tree tags were applied and DBH (diameter at $1.37 \mathrm{~m}$ above grade) and baseline tree health data (described below) were recorded. We 
recorded the percentage of each tanoak canopy that was surrounded by other tanoak canopies in $25 \%$ increments $(0=$ none, $1=1-25 \%, 2=26-50 \%, 3=51-75 \%, 4=76-100 \%)$. We used the same rating sytem to quantify the amount of canopy surrounded by phosphite-treated tanoaks, to account for potentially lower inoculum production from adjacent treated trees. We also recorded whether redwood or madrone canopy were adjacent to each tanoak canopy. Before the first phosphite application, we estimated the amount of moss present in the portion of the trunk where the spray was applied using a $0-6$ scale: $0=$ not seen, $1=$ up to $2.5 \%, 2=2.5-19 \%, 3=20-49 \%, 4=50-79 \%, 5=80-97.4 \%, 6=97.5-100 \%$. The scale is pretransformed using the arcsine transformation (Little and Hills 1978).

Tree condition was assessed at the start of the study and annually thereafter in the late summer or fall. The presence of bleeding trunk cankers was noted and their locations were recorded using cardinal directions and height above ground. The percent of trunk circumference affected by cankers was estimated using the pre-transformed 0-6 scale described above. At each annual evaluation, new suspect cankers were verified by using a hatchet to chip away small areas of outer bark to expose the canker edge. Suspect SOD cankers were sampled for the presence of $P$. ramorum by culturing small tissue pieces from the canker margin on PARP medium (Erwin and Ribeiro 1995) in petri plates. The percent of trunk circumference colonized by beetles or showing sporulation of Annulohypoxylon thouarsianum (Lév.) Y.M. Ju, J.D. Rogers \& H.M. Hsieh, and percent canopy dieback were also scored using the 0-6 scale above. Tree decline or mortality due to factors other than P. ramorum, trunk and root failures, and any other relevant symptoms were also recorded at each evaluation. In 2012, all tree locations were mapped using a combination of GPS coordinates and distance-azimuth measurements between trees, collected with a survey laser (Criterion 400, Laser Technology, Inc.).

Prior to the start of treatments, we collected 20 soil samples from throughout the area where trees were to be treated with phosphite. Elizabeth Fichtner (D. Rizzo lab, UC Davis) used rhododendron leaf disks to bait the samples for the presence of P. ramorum and other Phytophthora species (Fichtner et al. 2007).

Phosphite treatments - From 2008 through 2011, phosphite was applied at the product label rate: i.e., a $22.36 \%$ a.i. aqueous solution. In 2012, the applied solution concentration was increased to $29.8 \%$ a.i. In all years, Pentra-Bark ${ }^{\circledR}$ surfactant was added to the spray mix at the $2.3 \% \mathrm{v} / \mathrm{v}$ rate specified on the product label. Trunk diameters were used to calculate the amount of phosphite solution to apply to each trunk using methods described previously (Swiecki and Bernhardt 2007). Trees up to $30.5 \mathrm{~cm}$ DBH received 31 $\mathrm{ml}$ spray solution/cm DBH. For trunks larger than $30.5 \mathrm{~cm} \mathrm{DBH}$, the applied volume was calculated as follows:

$$
\text { total spray vol, } \mathrm{L}=-6.641803+0.1454801 \times(\mathrm{DBH}, \mathrm{cm})+0.0005723 \times([\mathrm{DBH}, \mathrm{cm}]-104.14)^{2}
$$

This formula increases the dose for large diameter trees so that the applied volume remains more closely proportional to bark/sapwood volume. The phosphite spray dose was applied to each trunk by calculating the time that each trunk needed to be sprayed based on the calculated spray amount and spray head delivery rate. The largest tanoak trunk $(93 \mathrm{~cm} \mathrm{DBH})$ received $6.97 \mathrm{~L}$ of spray solution $(75 \mathrm{ml} / \mathrm{cm} \mathrm{DBH})$ and required 3 minutes and 49 seconds of spray application time at the $30.4 \mathrm{ml} / \mathrm{sec}$ delivery rate of the spray head.

The initial application required about $477 \mathrm{~L}$ of phosphite solution to spray the 233 trunks. Phosphite was applied by Mayne Tree Expert Company (San Carlos, CA) using a 95 L spray tank with a 12 VDC electric pump. A digital motor speed controller was used to modulate the output of the sprayer. The sprayer head consisted of two TeeJet AI11003VS air induction nozzles oriented vertically so the long axis of the fan-shaped pattern was oriented along the trunk axis. The nozzles were mounted about $18 \mathrm{~cm}$ apart on a vertical frame and the sprayer head was mounted on a telescoping pole. To favor absorption through the thinner bark and maximize potential for absorption as residues were remobilized by rainwater, the 
spray was banded on the trunk starting at a height of about $6 \mathrm{~m}$ and applied downward, typically creating a band extending at least 2 to $3 \mathrm{~m}$ down the trunk (Figure 1). Sprayer calibration was checked at the start and periodically during each day of application by collecting and measuring the volume of solution delivered in 20 seconds. A pressure gauge at the base of the spray pole was monitored to assure that the sprayer remained in calibration. Total application volume was monitored by auditing the amount of material mixed and the amount of spray solution left over after each application and was typically within $5 \%$ of the target volume. Phosphite applications took 3 to 4 days by the 3-person crew and were completed within a one week period. November applications were scheduled to occur after the first autumn rains. In the first year of the study, initial phosphite applications were made at 6 month intervals, in May/June and again in November 2008. Subsequent applications were annual, completed in November from 2009 through 2012, after which phosphite applications were discontinued.

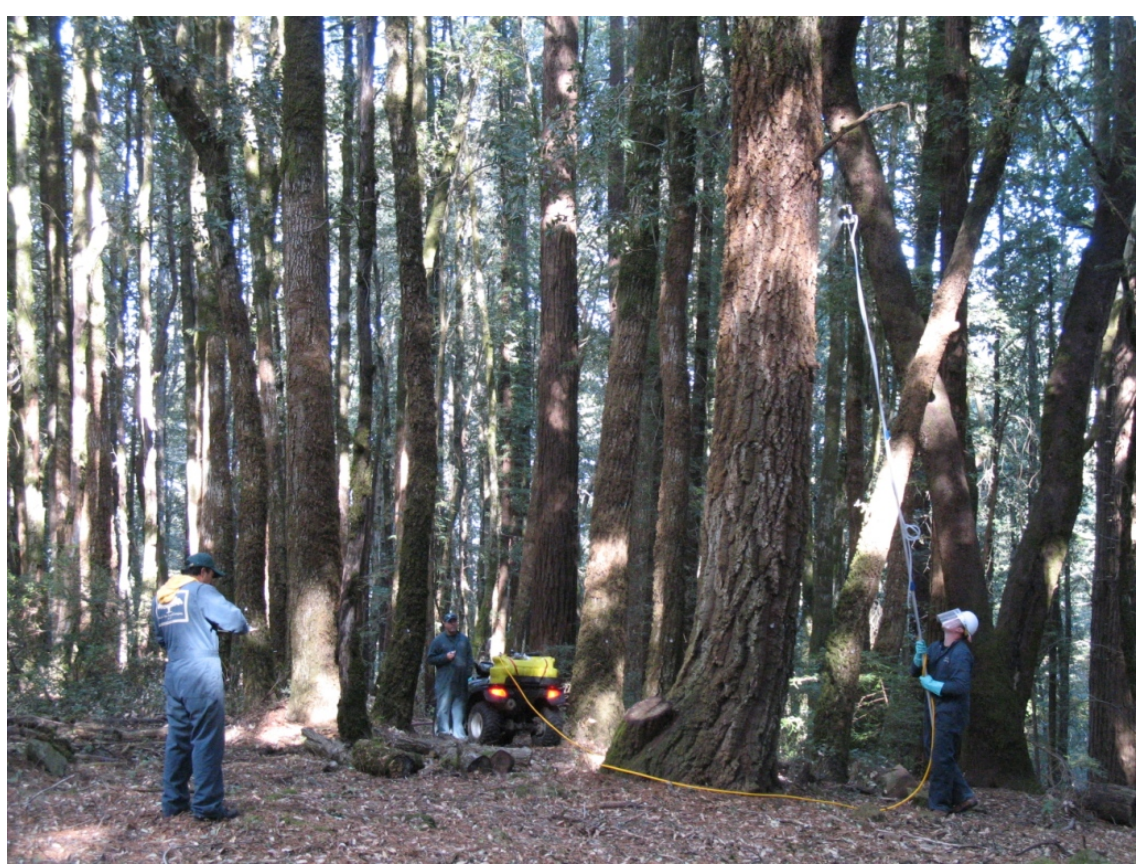

Figure 1. Phosphite trunk spray being applied high on the trunk of a mature tanoak in the SOD prevention study on the San Francisco Peninsula.

\section{Area-wide California bay removal: coast live oak}

Two areas with large mature coast live oaks near the Pulgas Water Temple on the SFPUC Peninsula Watershed (San Mateo County) were selected for area-wide bay removal. In both areas, California bays were dispersed throughout the understory as numerous saplings and a few small trees. Area-wide bay removal was conducted in a stand ( $0.5 \mathrm{ha}$ ) along a seasonal creek directly adjacent to the Pulgas Temple parking area and in a 0.4 ha section of a stand on a hillside about $200 \mathrm{~m}$ to the north of the first stand. Both stands are fenced to prevent public access. Within the stand adjacent to the parking area, one coast live oak had been removed prior to the start of our study; we could not determine whether it was killed by SOD. Mixed coast live oak-California bay stands with documented SOD mortality were present within 1 $\mathrm{km}$ of the treated area.

In September 2009, we tagged 77 coast live oaks (84 trunks, mean DBH $45 \mathrm{~cm}$, range 12-120 cm) within the treatment areas for monitoring. Individual trunks of multitrunked oaks commonly have different disease outcomes (Swiecki and Bernhardt 2013) and were monitored separately. Several trees had bleeding cankers, but isolations from cankers were negative for P. ramorum and other Phytophthora spp. 
Some of the observed bleeding was associated with sycamore borer, Synanthedon resplendens Hy. Edwards (Sesiidae). California bays were removed from the treated areas in October 2009, with follow-up work completed by January 2010. All felled material was removed from the treated areas and chipped. We selected control trees from the nearest available area, a coast live oak-dominated stand with variable California bay cover, about $1 \mathrm{~km}$ west of the treated stands. In this area, many of the oaks already had SOD symptoms in areas with dense bay cover. We tagged 48 uninfected control trees (59 trunks, mean DBH $32 \mathrm{~cm}$, range 11-74 cm), mostly around scattered individual bay trees.

Baseline oak health data was collected as described above for tanoak at the start of the study and every one to two years thereafter. Variables describing California bay distribution and density around each oak trunk were recorded at the start of the study and at each subsequent evaluation. For treated oak trunks, measurements were made before and after bay removal. We used a $500 \mathrm{~mW}$ green laser attached to an angle gauge to project a plumb line to the edge of bay canopy nearest to each oak trunk. A laser rangefinder was used to measure the horizontal distance from this vertical line to the oak trunk (bay foliage-oak trunk distance). We visually estimated the bay canopy cover for zones within 2.5 and $5 \mathrm{~m}$ of each oak trunk using a modified quarter scale: $0=0 \%$ cover, $0.1=$ trace amounts of cover $(<1 \%), 1=1$ $25 \%$ cover, $2=26-50 \%$ cover, $3=51-75 \%$ cover, and $4=$ more than $75 \%$ bay cover. We also noted whether overstory or understory bay trees were present within 10 and $20 \mathrm{~m}$ of the oak trunk and if bay seedlings were located within $1 \mathrm{~m}$ of the oak trunk.

\section{Area-wide California bay removal: Shreve and canyon live oak}

We also tested area-wide bay removal in a stand of Shreve oaks at the Monte Bello Open Space Preserve in San Mateo County. The treated area (about $2.5 \mathrm{ha}$ ) was roughly circular and was dominated by mature Shreve oaks, but included some canyon live oaks. Within the treated area, California bay occurred mostly as scattered, small diameter understory seedling and saplings and a small a number of large, mostly multitrunked trees. Prior to bay removal, we tagged 73 oaks for monitoring: 58 Shreve oak trees (73 trunks, mean DBH $36 \mathrm{~cm}$, range $11-81 \mathrm{~cm})$, and 15 canyon live oak trees $(18$ trunks, mean DBH $43 \mathrm{~cm}$, range 11-102 cm). We also tagged 74 oaks located beyond the edges of the treated area to serve as controls: 63 Shreve oak ( 76 trunks, mean DBH $33 \mathrm{~cm}$, range 12-80 cm), and 11 canyon live oak trees $(13$ trunks, mean DBH $37 \mathrm{~cm}$, range 6-92 cm). For all tagged trunks, we recorded baseline health data, oakbay clearance, and bay cover within 2.5 and $5 \mathrm{~m}$ of each trunk as described above for coast live oaks. A few trunks in each treatment already had SOD symptoms.

Removal of California bay trees, saplings, and seedlings was initiated in December 2008 and completed in March 2009. Stumps of removed trees were immediately treated with glyphosate ( $20.5 \%$ a.i. solution) to suppress resprouting. Felled material was left on site after being cut in small pieces and dispersed away from oak trunks (lopped and scattered). In March 2009, 13 California bays that were too large to fell with the available crew were treated with glyphosate by making downward-angled cuts around the circumference of the trunks using a hatchet and immediately spraying glyphosate ( $20.5 \%$ a.i. solution) into the cuts using a backpack sprayer (known as frill girdle or hack-and-squirt application). Three large bays in the treated area were inadvertently skipped in March and were treated by frill application in July 2009 and again in May 2010 and December 2011. Bay trees along a creek that bordered the treated area were not removed.

After California bay removal, we remeasured bay clearance and cover variables for monitored trees within the treated area. Some oaks in the treated area had low bay foliage-oak trunk clearances for the first few years of the study because a few of the bays treated with the glyphosate frill application died slowly. Bay clearances and health data were reassessed every one to two years. 


\section{Localized California bay removal: coast live and California black oak}

We studied the effect of localized bay removal around individual coast live or California black oaks in mixed hardwood stands at six locations in Sonoma, Napa, and Solano Counties. At the start of the study in 2007, P. ramorum had been confirmed at all study locations and was causing symptoms on California bay and coast live or California black oaks. The latent period for SOD in oaks is typically at least 1 to 2 years (Swiecki and Bernhardt 2015), so new symptoms observed in the first post-treatment evaluation (June 2008) were assumed to have resulted from infections that occurred prior to treatment. This was especially likely because 2005 and 2006 had high rainfall levels that were associated with new SOD infections at other monitored sites (Swiecki and Bernhardt 2015) whereas 2007 was a drought year with a very dry spring which was unfavorable for SOD infections. To account for the latent infections that existed at the start of the study, disease status in June 2008 was used as the pre-treatment baseline.

Within each location, baseline data were collected on candidate study trees to allow for selection of trees within each location that were matched with respect to factors related to disease risk, including DBH, skyexposed canopy, unweathered bark fissures, distance to California bay and the amount of bay within 2.5 and $5 \mathrm{~m}$ of the trunk (Swiecki and Bernhardt 2002, 2015), and the presence of $P$. ramorum cankers and current year bleeding. We initially selected a total of 31 coast live oak pairs (mean DBH $41 \mathrm{~cm}$, range 18$89 \mathrm{~cm}$ ) and 18 California black oak pairs (mean DBH $59 \mathrm{~cm}$, range $22-130 \mathrm{~cm}$ ).

One tree of each pair was randomly assigned as the control and was not altered in any way. For the other (treated) tree, we removed bay nearest to the trunk to achieve a minimum bay foliage-oak trunk clearance of 2.5-5 m. Minimum clearances were increased to $5 \mathrm{~m}$ or more where feasible, especially in the direction of the prevailing storm winds. If present, poison oak climbing in the tree canopy was killed by cutting stems at ground level (Swiecki and Bernhardt 2013). Bay removal was initiated in January 2007 and completed in November 2007. At the June 2008 baseline, there were 40 matched pairs in which both the treated and control tree were asymptomatic (24 coast live oak pairs, 16 California black oak pairs).

The target bay foliage-oak trunk clearance was usually achieved by removing small-diameter bays close to the oak and/or bay branches from bays located farther from the oak. In some cases, very high bay canopy (above $8 \mathrm{~m}$ ) could not be reached using a pole pruner and the bay trunks were too large to fell. In such cases, we removed as much of the lower, shaded bay canopy within the target clearance zone as possible. We have previously observed that $P$. ramorum symptoms are normally much more common on low bay foliage than on leaves at the top of the canopy. During the 2008, 2009 and 2010 evaluations, additional bay branches or stems were cut where possible to maximize and stabilize oak-bay clearances for treated trees. These adjustments helped maintain target clearances in most cases and reduced California bay cover within $5 \mathrm{~m}$ of the trees in situations where clearances were less than the $2.5-5 \mathrm{~m}$ target.

Tree health, SOD symptoms, and oak-bay clearance and cover variables were reevaluated annually as described above. At each evaluation, we also recorded whether $P$. ramorum foliar symptoms were present on bay in the zones $0-2.5 \mathrm{~m}$ and $2.5-5 \mathrm{~m}$ from the oak trunk.

\section{Data analyses}

Analyses of the tanoak phosphite study are complicated by possible but unknown non-independence of experimental units. Because P. ramorum inoculum is produced on tanoaks, disease outcomes could be influenced by neighboring trees to differing degrees within the treated and control populations. Logistic regression analyses to examine tree and plot factors related to disease outcomes were therefore conducted within treated and control populations separately using JMP statistical software (SAS Institute Inc., Cary, NC). The binary disease outcome in these analyses was SOD symptom presence in 2013, one year after the last phosphite application, which was the last year when maximum phosphite activity would have 
been expressed. Exact binomial confidence intervals (Clopper and Pearson 1934) were plotted to compare the proportions of symptomatic trees between treatments.

Due to the different epidemiology of SOD in oaks (no inoculum production on oaks), the assumption of independence is valid in the oak studies. For the localized bay removal study, matched pairs statistics (McNemar and Cochran-Mantel-Haenszel tests) were used to test for the significance of treatment effects in paired observations. Some oaks were infected before the study was initiated, but reported analyses consider only oak trunks that were free of SOD symptoms at the study baseline date.

In addition, logistic regression models were constructed for the binary disease outcome (SOD symptoms present or not) to test whether binary disease outcomes were related to tree-specific risk variables and to assess the significance of individual bay neighborhood and oak-based risk variables. Analyses were conducted on the final set of tree disease assessments. Comparisons of logistic models were made using both the corrected Akaike information criterion (AICc) and Bayesian information criterion (BIC).

\section{Results}

\section{Phosphite application to tanoak trunks}

No Phytophthora species were detected in the study area in the 2008 soil samples and no evidence of $P$. ramorum was observed in the study area until twig blighting of understory tanoak was first observed in spring 2011 in a control area. By fall 2011, twig blighting was widespread and P. ramorum was isolated from twigs and leaves of understory tanoaks in the phosphite treated area and all of the control areas. At that time, scattered overstory tanoaks in phosphite-treated and control areas also showed foliage blighting consistent with $P$. ramorum symptoms in their high canopies. No $P$. ramorum trunk cankers were observed in the fall 2011 annual health evaluations, but several tanoaks had nearly complete canopy dieback by April 2012. In the fall 2012 evaluation, P. ramorum trunk cankers were confirmed on tanoaks in the phosphite-treated area and all four control areas.

Initially, very few of the symptomatic tanoaks showed bleeding associated with $P$. ramorum cankers. Over time, the incidence of bleeding cankers in symptomatic trees increased, but was still below 50\% overall in 2016 among trees showing late SOD symptoms (secondary attack by beetles and or Annulohypoxylon thouarsianum). Many affected trees developed high bole cankers and had dead tops even though we could not detect cankers in the lower $2.5 \mathrm{~m}$ of the trunk. We used binoculars to scan the upper portions of the boles for higher bleeding cankers, but could not see evidence of bleeding in the upper boles. In some trees with dead canopies and no external bole symptoms, chipping of the bark revealed cankers with bottom edges $1.5 \mathrm{~m}$ or more above ground level. We were able to verify one high bole canker (starting at a height of $9.6 \mathrm{~m}$ ) in a tree that was cut down in May 2013. P. ramorum was isolated from most of the bark cankers we sampled.

As shown in Figure 2, SOD symptoms and SOD-related mortality appeared in similar proportions of phosphite-treated and control tanoaks in fall 2012, indicating that phosphite application did not delay the onset of the epidemic within the treated population. Given this apparent lack of efficacy after 4 years of phosphite application at the standard application rate $(22.4 \%$ solution), we applied a higher phosphite dose (same spray volumes per tree but using $29.8 \%$ solution) to study trees in fall 2012 . By fall 2013 , one year following this final phosphite application, the proportion of tanoak trunks with SOD symptoms was significantly higher in the phosphite-treated population than the controls (Figure 2). 

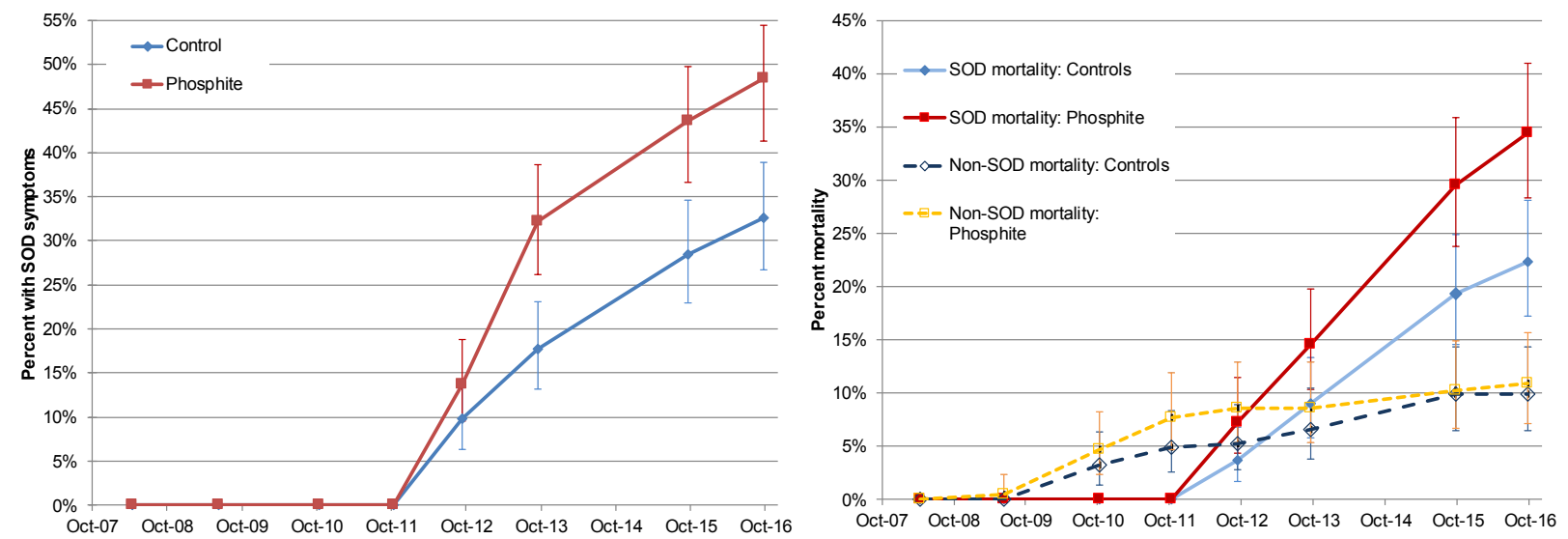

Figure 2. Incidence of SOD trunk symptoms (left) and mortality due to SOD and other causes (right) in mature tanoaks either treated annually with potassium phosphite from May 2008 through November 2012 (phosphite) or left untreated (controls). Phytophthora ramorum foliar symptoms first appeared in the study populations in 2011. Error bars are 95\% exact binomial confidence intervals.

Cessation of phosphite treatments after 2012 had no apparent effect on the increase in SOD incidence or mortality over time in the treated trees compared to the controls, based on fall 2015 and 2016 evaluations (Figure 2). This is a further indication that the phosphite treatment had no effect on disease development. In 2016, both SOD incidence and SOD-related mortality were significantly higher among phosphitetreated trees than controls (Figure 2). The distribution of SOD-affected trees in the study area was nonuniform with evident spatial clustering (Figure 3). Logistic regression models within treated and control populations did not identify any significant tree-related predictors for the binary disease outcome SOD symptoms in 2013. Variables tested that were not significant predictors (likelihood ratio $\chi^{2} \mathrm{p}>0.05$ in all models) of SOD included trunk DBH, the amount of adjacent tanoak canopy (0-4 rating), and presence of adjacent redwood or madrone canopy. For the phosphite-treated area, the degree to which treated tanoaks were surrounded by other treated tanoaks (0-4 rating) was not significantly related to SOD symptoms.

All of the phosphite treated tanoaks had moss covering at least $50 \%$ of their stems. Moss on trunks was killed by the initial phosphite application and subsequently degraded. Any absorption of spray by moss would have been limited to the first year of treatment, several years before the pathogen was detected in the study area. Moss rating was not a significant predictor of the 2013 binary SOD outcome in singlevariable or multivariable logistic regression models (likelihood ratio $\chi^{2} \mathrm{p}=0.1754$ single variable model). Prior to the appearance of SOD-related mortality in 2012, scattered mortality due to Armillaria root disease, noted at the study start, continued to increase slowly in the study area (Figure 2). Over the 8.5 years of observation, mortality due to factors other than SOD was $10.4 \%$ overall (average $1.2 \%$ per year), and was nearly identical in phosphite-treated and control trees (Figure 2). By December 2016, SODrelated mortality across control and treated populations (28.2\% overall) significantly exceeded background mortality due to other factors (Figure 2). SOD-related mortality averaged $7.1 \%$ per year between 2012 and 2016. 


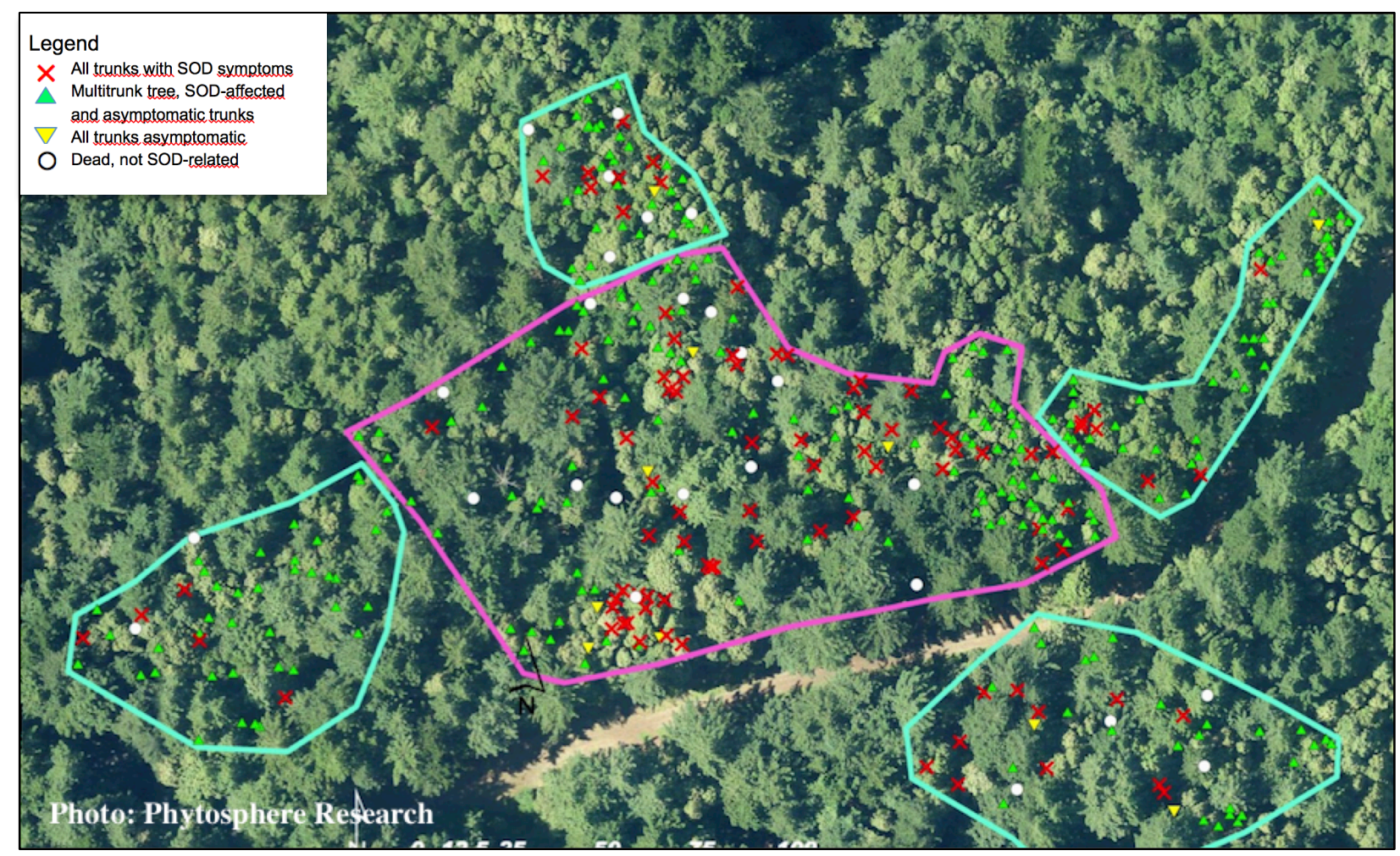

Figure 3. Distribution of tanoaks with SOD symptoms or non-SOD mortality in fall 2013 in tanoaks treated with potassium phosphite trunk applications (May 2008-November 2012) (pink border) or left untreated (control) (turquoise border). Photo date 2011.

\section{Area-wide California bay removal: coast live oak}

Through September 2016, no SOD infections had occurred among the monitored coast live oaks in bay removal areas at the Pulgas study location. In the control cohort, SOD symptom incidence has increased gradually (Figure 4). By December 2016, about 25\% (15/59) of the untreated control trees had developed SOD symptoms and ten of these trees (17\% of controls) had been killed by SOD. Initial bay foliage-oak trunk clearances of the SOD-affected control trees ranged from 0 to $2.5 \mathrm{~m}$.

\section{Area-wide California bay removal: Shreve and canyon live oak}

Shreve oak - Through 2016, area-wide bay removal has been effective in preventing SOD among Shreve oaks in the treated area. Among trees without SOD symptoms in 2009, 20\% (13/66) of control trunks developed SOD symptoms by 2016, whereas no new SOD symptoms were seen among the 60 Shreve oak trunks in the bay removal area (Figure 4). Overall, 39\% (9/23) of the monitored trees that had SOD symptoms in 2009 were dead by 2016. Percent mortality in this initially-infected cohort was nearly equal for both control and bay removal plots. However, complete symptom remission developed in one initially symptomatic oak in the bay removal area over the observation period.

Canyon live oak - Ten of the control canyon live oaks were asymptomatic in 2009; three of these (30\%) developed symptoms by 2016. All 18 of the monitored canyon live oak trunks in the bay removal area were initially symptomless, but three trunks (17\%) developed late SOD symptoms by 2016.

However, $P$. ramorum-infected canyon live oaks typically do not bleed (Swiecki et al. 2016) and SOD symptoms are normally cryptic until secondary organisms attack, so it is possible that some or all of these trees $(28,91$, and $102 \mathrm{~cm} \mathrm{DBH})$ were infected before the start of the study. Due to the small sample size 
for canyon live oak, data from additional studies currently in progress will be needed to assess the effectiveness of bay removal for protecting this species from $P$. ramorum.
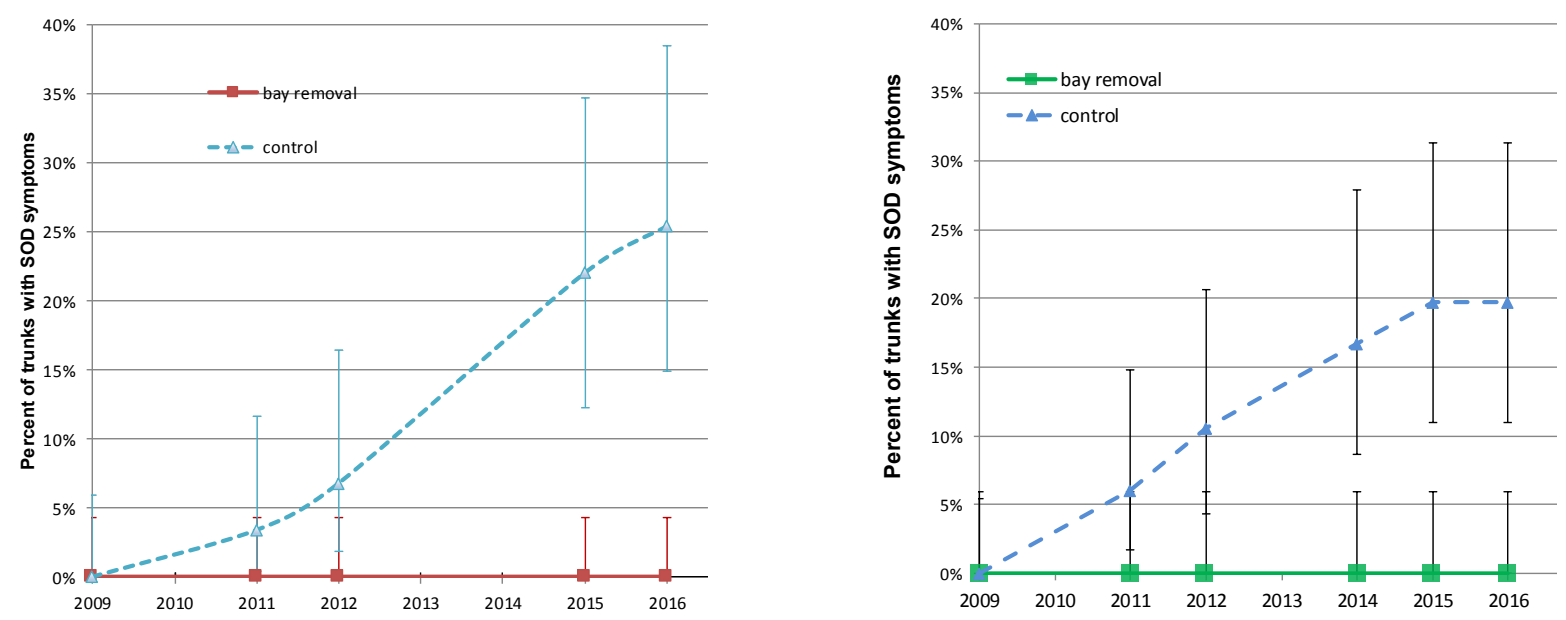

Figure 4. SOD incidence (2009-2016) in initially asymtomatic oaks in areas treated by California bay removal (solid lines) and untreated control areas (broken lines). Left - coast live oaks on the SFPUC Peninsula Watershed. Right - Shreve oaks at Monte Bello Open Space Preserve. Error bars are 95\% exact binomial confidence intervals.

Oak - California bay clearances - Initial bay foliage-oak trunk clearances (2009) for controls averaged $0.8 \mathrm{~m}$ (range 0 to $6.5 \mathrm{~m}$ ) and were nearly identical in 2016. Minimum bay foliage-oak trunk clearances of the oaks that developed new SOD symptoms between 2009 and 2016 ranged from 0 to $1.5 \mathrm{~m}$. Before treatment, bay foliage-oak trunk clearances averaged $1.9 \mathrm{~m}$ (range 0 to $11.9 \mathrm{~m}$ ) among tagged trees in the bay removal area. After area-wide bay removal, most monitored oak trunks were at least $20 \mathrm{~m}$ from the nearest bay foliage. Exceptions included a few oaks near the edges of the California bay removal area and near some glyphosate-treated bay trees that did not die until several years after treatment. In 2016, eight monitored oak trunks in the bay removal area were less than $20 \mathrm{~m}$ from bay foliage (range 5.6 $\mathrm{m}$ to $15.1 \mathrm{~m})$.

Of the 13 California bay trunks treated with herbicide in March 2009, most were completely top-killed by August 2009. By November 2009, 7 of 13 treated trunks were dead, 5 had more than $90 \%$ dieback, and one had at least $80 \%$ dieback. In contrast, the three bays treated in July 2009 showed some chlorosis by August 2009 and were chlorotic with some canopy thinning by November 2009. The trees improved somewhat in condition over the winter and were still in fair condition in March 2010. The second frill application of glyphosate applied to these trees in May 2010 was mostly ineffective. The third treatment in December 2011 killed the tops of these bays by October 2013. These results are consistent with observations at other sites showing that glyphosate application to kill bay is only effective in the wet winter months.

\section{Localized California bay removal around coast live and California black oak}

Among the 40 oak pairs that were asymptomatic in the 2008 evaluations, 8 pairs of trees had discordant outcomes by 2013 (Table 1). All of these were pairs in which the control oak developed SOD symptoms while the treated oak remained asymptomatic. This difference was significant using both McNemar's test ( 2 tail $p=0.0078$ ) and the Cochran-Mantel-Haenszel test $(\mathrm{p}=0.0047)$. All oaks in the study initially had 
bay foliage overtopping or within $1.2 \mathrm{~m}$ of their trunks and had variable amounts of bay cover within $5 \mathrm{~m}$ of the trunk. Control oaks continued to have little or no clearance from bay foliage (2013 mean $0.04 \mathrm{~m}$, range $0-1 \mathrm{~m}$ ). After initial bay removal, bay foliage-oak trunk clearance averaged $5.2 \mathrm{~m}$ (range $1.25-7 \mathrm{~m}$ ) in treated trees. Due to clearance maintenance during annual health evaluations, bay foliage-oak trunk clearance averaged $5.7 \mathrm{~m}$ (range 1.1 to $10.8 \mathrm{~m}$ ) in 2013. One asymptomatic treated oak had bay canopy within $2.5 \mathrm{~m}$ (cover rating =1) and only two had bay foliar symptoms within $5 \mathrm{~m}$ in 2013.

Table 1. Disease outcomes as of 2013 for matched tree pairs in which one tree was treated with local bay removal and the other left as an untreated control. Only discordant pairs (paired trees with different outcomes) are considered in paired analyses.

\begin{tabular}{|c|c|c|c|c|}
\hline & \multicolumn{2}{|c|}{ Concordant pairs } & \multicolumn{2}{|c|}{ Discordant pairs } \\
\hline & Both asymptomatic & Both with SOD & SOD - control only & SOD - treated only \\
\hline Black oak & 12 & 0 & 4 & 0 \\
\hline Coast live oak & 18 & 2 & 4 & 0 \\
\hline Total & 30 & 2 & 8 & 0 \\
\hline
\end{tabular}

Both of the coast live oaks in the bay removal treatment that developed SOD symptoms (Table 1) had bay foliage directly over their trunks prior to treatment. One of these had bay foliage-oak trunk clearance of $3.5 \mathrm{~m}$ at treatment, but clearances had declined to $1.7 \mathrm{~m}$ by the time that symptoms were first observed (2009) and bay foliage was directly above major scaffold branches that could funnel water flow to the trunk. The bay clearance of the other tree was within the target range $(5.3 \mathrm{~m}$ horizontal distance between bay foliage and trunk) when it became symptomatic in 2010, but bay foliage was located within $1.5 \mathrm{~m}$ of major scaffold branches that drained to the trunk.

Because of variations in local stand composition, the local bay removal treatment resulted in a range of bay clearances and cover levels around treated oaks. To examine the risks associated with local bay cover and clearance and tree variables in greater detail, we constructed logistic regression models for SOD symptoms in 2013 (a binary outcome) for all trees that were asymptomatic in 2008 (Table 2). Comparison of single predictor models showed that a number of correlated variables describing the local bay neighborhood within 2.5 or $5 \mathrm{~m}$ of the trunk, including the treatment variable, were significant and had similar predictive power (Table 2). Observed bay foliar symptoms (2013) within $5 \mathrm{~m}$ of the oak trunk was a better predictor than bay cover and distance variables, but this variable is obviously correlated with the presence of bay foliage within this distance. Among oak-related variables, only unweathered bark fissures (at least $20 \%$ of trunk having fissures showing recent expansion) was a significant predictor (likelihood ratio $\left.\chi^{2} \mathrm{p}=0.0224\right)$ in single predictor models. This variable has been a strong predictor of SOD in other studies (Swiecki and Bernhardt 2015). Trunk DBH was a much weaker predictor of SOD in this population and was not significant in single-predictor models.

Table 2. Summary of single-parameter logistic regression models for the binary SOD outcome (SOD symptoms present or not) in coast live oaks and California black oaks 5 years after the start of the matched pairs localized California bay removal study.

\begin{tabular}{|c|c|c|c|c|c|}
\hline Predictor & Variable type & $\begin{array}{c}\text { Likelihood ratio } \mathrm{X}^{2} \\
\mathrm{P} \text { level }\end{array}$ & $\mathrm{R}^{2}$ & $\mathrm{AICc}$ & $\mathrm{BIC}$ \\
\hline Unweathered bark fissure rating $\geq 3$ & binary & 0.0224 & 0.0844 & 60.7560 & 64.8771 \\
\hline California bay foliar symptoms within $5 \mathrm{~m}$ & binary & 0.0004 & 0.1820 & 61.0024 & 65.7666 \\
\hline California bay cover within $2.5 \mathrm{~m}$ & categorical & 0.0040 & 0.1191 & 65.3746 & 70.1387 \\
\hline California bay cover within 5 m & categorical & 0.0050 & 0.1133 & 65.7746 & 70.5387 \\
\hline Minimum oak bay distance & continuous & 0.0055 & 0.1111 & 65.9327 & 70.6968 \\
\hline Treatment- California bay removed or not & binary & 0.0093 & 0.1000 & 65.0239 & 69.6321 \\
\hline $\mathrm{DBH}, \mathrm{cm}$ & continuous & 0.0838 & 0.0742 & 96.1721 & 109.314 \\
\hline
\end{tabular}




\section{Discussion}

\section{Phosphite application to tanoak trunks}

Reduced P. ramorum lesion expansion has been reported in phosphite-treated trees (Garbelotto et al. 2007, Garbelotto and Schmidt 2009). However, in this large trial, which used diameter-scaled dosages, phosphite stem spray application did not protect tanoaks from SOD. The initial invasion of the stand by $P$. ramorum was not impeded by the previous three years of phosphite stem-spray applications. In addition, no slowing of canker development or mortality was seen in phosphite-treated trees. In a previous study using similar study protocols on 63 treated and 133 control tanoaks in Sonoma County, we also observed no disease suppression from trunk spray applications of phosphite. In that study, controls had lower levels of SOD incidence and mortality than tanoaks treated for 6 years with phosphite trunk sprays (Bernhardt and Swiecki 2013). While we cannot rule out that stem-spray applications of phosphite could suppress SOD development in tanoak under some conditions, results from these studies indicate that this treatment is not effective in all stands.

The observed lack of phosphite efficacy in the tanoak treated by trunk spray application may be related to inadequate absorption of phosphite through the outer bark. The outer bark of mature tanoaks poses a significant barrier to phosphite absorption compared to the thin bark of young trees used in greenhouse tests. Even if some phosphite was absorbed by treated trees, it may not have accumulated to adequate levels in tissues where activity needs to be expressed, i.e., living phloem of the bole and in twig tissue. The distribution of SOD-affected trees within the treated stand and the lack of a preponderance of SODaffected trees around plot edges in the treated population (Figure 3) suggest that phosphite application did not suppress foliar and twig infections or spore production in the canopy.

SOD incidence was significantly higher in the phosphite-treated trees than in the surrounding control areas (Figure 2). Differences in disease incidence across the study area appear to be related to the uneven spatial distribution of the disease across the stand. The large differences in SOD incidence that can occur across a relatively small area, especially early in the local epidemic, could lead to misinterpretation of treatment effects on disease outcomes in studies using relatively small plots. Lack of treatment efficacy can be safely concluded when high levels of disease develop among treated trees. However, in studies that rely on natural spread of inoculum into plots, it is difficult to interpret whether higher levels of disease in control plots compared to treated plots are meaningful without long-term monitoring.

\section{California bay removal around SOD-susceptible oaks}

Based on the epidemiology of P. ramorum observed in SOD-affected oaks in California (Swiecki and Bernhardt 2013), it is not surprising that pruning or removing California bay close to oak trunks greatly reduced their likelihood of developing SOD symptoms. Variables describing the proximity and density of California bay around individual trees are the strongest predictors of SOD development in coast live oak in California forests (Swiecki and Bernhardt 2015). P. ramorum infects bay foliage and sporulates abundantly on it, but does not sporulate on coast live oak trunk cankers (Davidson et al. 2002, 2005). The amount of $P$. ramorum inoculum dispersed from bay canopies decreases strongly as the distance from the bay canopy source increases from 0 to $5 \mathrm{~m}$ or beyond (Davidson et al. 2005).

Where practical and consistent with other management objectives, area-wide removal of California bay appears to provide the greatest level of SOD prevention for stands of susceptible oaks (Swiecki and Bernhardt 2013). Area-wide bay removal maximizes the distance between inoculum sources and susceptible oaks, thereby minimizing exposure to inoculum. Studies with coast live oak and Shreve oak (Figure 2) show complete disease suppression over 7 years, but continued monitoring of these bay removal studies is needed to determine long-term efficacy under weather conditions that generate very high inoculum levels. Several drought years, which are unfavorable for P. ramorum reproduction, occurred during the reported study period. 
Data from the matched pairs study suggests that local reduction of bay canopy around susceptible oaks can significantly reduce SOD risk. However, the importance of bay canopy close to oaks can be seen across all bay removal studies in that most oaks that became infected had bay canopy within $1 \mathrm{~m}$ of the trunk. Eliminating California bay cover within a zone no more than 2.5 to $5 \mathrm{~m}$ around oak trunks provides a viable option for reducing SOD risk in stands where landscape-level bay cover and bay foliar infection levels are low or where conditions are less favorable for inoculum production (Swiecki and Bernhardt 2013). This strategy may also be appropriate for reducing SOD risk in high-value oaks in locations where area-wide bay removal is not feasible or desirable.

Responses of oaks to $P$. ramorum vary greatly, with many trees expressing resistant or tolerant reactions to infection (Swiecki and Bernhardt 2013, McPherson et al. 2015). Consequently, some oaks with overhanging California bay foliage may resist infection, whereas highly susceptible individual oaks sometimes become infected where bay foliage-oak trunk clearances are greater than 10 to $20 \mathrm{~m}$. In such situations, infections appear to be initiated by small numbers of spores, either blown by wind or vectored by animals or human activities. While bay removal may not protect all susceptible individual oaks, it has the potential to greatly reduce or largely eliminate SOD impacts in a variety of situations.

\section{Acknowledgements}

Funding was provided by U.S. Forest Service, Pacific Southwest Research Station, and State and Private Forestry, Forest Health Protection; Midpeninsula Regional Open Space District (MROSD); San Francisco Public Utilities Commission (SFPUC); and Phytosphere Research. We thank Bill Stringfellow, Quest Products, for donations of potassium phosphite and Pentra-Bark ${ }^{\circledR}$ used in this study. We thank Susan Frankel and Phil Cannon, USFS; Cindy Roessler, Scott Cotterel, and Stan Hooper (MROSD); Ellen Natesan (SFPUC); and Elizabeth Fichtner and Dave Rizzo, UC Davis, for support and assistance. We thank Chris Drake, Professor of Statistics, UC Davis, for suggestions regarding statistical analysis of the data. We thank two anonymous reviewers and Susan Frankel for suggestions on ways to improve this paper.

\section{Literature cited}

Bernhardt, E. A., Swiecki, T. J. 2013. Management of Phytophthora ramorum in tanoak and oak stands: Final report, June 2013. 12p. http://phytosphere.com/publications/2013 June Phytosphere Final Report 11-JV-076.pdf (1 August 2017).

Clopper, C. J., Pearson, E. S. 1934. The use of confidence or fiducial limits illustrated in the case of the binomial. Biometrika 26:404-413.

Cunniffe, N. J., Cobb, R. C., Meentemeyer, R. K., Rizzo, D. M., Gilligan, C. A. 2016. Modeling when, where, and how to manage a forest epidemic, motivated by sudden oak death in California. Proc. Natl. Acad. Sci. USA 113:5640-5645.

Davidson, J. M., Rizzo, D. M., Garbelotto, M, Tjosvold, S, Slaughter, G. W., Koike, S. T. 2002. Phytophthora ramorum and sudden oak death in California: II. Transmission and survival. Pages 741-749 in USDA Forest Service Gen. Tech. Rep. PSW-GTR-184.

Davidson, J. M., Patterson, H. A., Rizzo, D. M. 2008. Sources of inoculum for Phytophthora ramorum in a redwood forest. Phytopathology 98:860-866.

Davidson, J. M., Wickland, A. C., Patterson, H. A., Falk, K. R., Rizzo, D. M. 2005. Transmission of Phytophthora ramorum in mixed-evergreen forest in California. Phytopathology 95:587-596.

Erwin, D. C., and Ribeiro, O. K. 1996. Phytophthora Diseases Worldwide. APS Press, St. Paul, MN. 562 pp. 
Fichtner, E. J., Lynch, S. C., Rizzo, D. M. 2007. Detection, distribution, survival, and sporulation of Phytophthora ramorum in a California redwood-tanoak forest soil. Phytopathology 97:1366-1375.

Garbelotto, M., Schmidt, D. J., Harnik, T. Y. 2007. Phosphite injections and bark application of phosphite + Pentrabark ${ }^{\mathrm{TM}}$ control sudden oak death in coast live oak. Arboriculture \& Urban Forestry 33:309-317.

Garbelotto, M., Schmidt, D. J. 2009. Phosphonate controls sudden oak death pathogen for up to 2 years. Calif. Agric. 66:10-17.

Guest, D., Grant, B. 1991. The complex action of phosphonates as antifungal agents. Biol. Rev. Biol. Proc. Cambridge Philos. Soc. 66:159-187.

Hardy, G. E. St. J., Barrett. S., Shearer, B. L. 2001. The future of phosphite as a fungicide to control the soilborne plant pathogen Phytophthora cinnamomi in natural ecosystems. Australas. Plant Pathol. 30:133-139.

Little, T. M., Hills, F. J. 1978. Agricultural experimentation: Design and analysis. New York: John Wiley and Sons.

McPherson, B. A., Mori, S. R., Conrad, A. O., Opiyo, S., Bonello, P., Wood, D. L. 2015. Biomarkers identify coast live oaks that are resistant to the invasive pathogen Phytophthora ramorum. Pages 543-551 in: Proceedings of the seventh California oak symposium: managing oak woodlands in a dynamic world, Visalia, California. Standiford, R. B., McCreary, D., Purcell, K.L., tech. coords. Gen. Tech. Rep. PSW-GTR-251. Berkeley, CA. Pacific Southwest Research Station, Forest Service, U.S. Department of Agriculture.

Rizzo, D., Garbelotto, M., Davidson, J., Slaughter, G., Koike, S. 2002. Phytophthora ramorum as the cause of extensive mortality of Quercus spp. and Lithocarpus densiflorus in California. Plant Dis. 86(3):205-214.

Swiecki, T. J., Bernhardt, E. A. 2002. Evaluation of stem water potential and other tree and stand variables as risk factors for Phytophthora ramorum canker development in coast live oak. Pages 787-798 in: Proceedings of the fifth symposium on oak woodlands: oaks in California's changing landscape. Standiford, R. B., McCreary, D., Purcell, K. L., tech. coords. Gen. Tech. Rep. PSW-GTR-184. Albany, CA. U.S. Department of Agriculture, Forest Service, Pacific Southwest Research Station, p. 787-798.

Swiecki, T. J., Bernhardt, E. 2007. Management of Phytophthora ramorum in tanoak and oak stands, progress report \#3. Vacaville, CA: Phytosphere Research. http://phytosphere.com/publications/Dec2007_Progress_report_06-JV040_SOD_mgmt.pdf. 14 p. (1 August 2017)

Swiecki, T. J., Bernhardt, E. 2008. Increasing distance from California bay reduces the risk and severity of Phytophthora ramorum canker in coast live oak. Pages 181-194 in: Proceedings of the Sudden Oak Death Third Science Symposium, Santa Rosa, CA. Frankel, S. J.; Kliejunas, J. T.; Palmieri, K. M., tech. coords. Gen. Tech. Rep. PSW-GTR-214, Albany, CA. Pacific Southwest Research Station, Forest Service, U.S. Department of Agriculture.

Swiecki, T. J., Bernhardt, E. A. 2013. A reference manual for managing sudden oak death in California. Gen. Tech. Rep. PSW-GTR-242. Albany, CA. U.S. Department of Agriculture, Forest Service, Pacific Southwest Research Station. 129 pp.

Swiecki, T. J., Bernhardt, E. 2015. Phytophthora ramorum canker (sudden oak death) disease risk and progress in coast live oak, 2000-2012. Pages 563-572 in: Proceedings of the seventh California oak symposium: managing oak woodlands in a dynamic world, Visalia, California. Standiford, R. B., McCreary, D., Purcell, K.L., tech. coords. Gen. Tech. Rep. PSW-GTR-251. Berkeley, CA. Pacific Southwest Research Station, Forest Service, U.S. Department of Agriculture.

Swiecki, T., Bernhardt, E. 2016. Sudden oak death in California. Pages 731-756 in: Insects and diseases of Mediterranean forest systems. Paine, T. D., Lieutier, F. Eds.. Switzerland: Springer International Publishing.

Swiecki, T. J., Bernhardt, E. A., Aram, K., Rizzo, D. M., Kasuga, T., and Bui, M. 2016. Phytophthora ramorum causes cryptic bole cankers in canyon live oak. Plant Health Prog. 17:20-26.

U.S. Environmental Protection Agency [USEPA]. 1998. Mono- and di-potassium salts of phosphorous acid (076416) fact sheet. https://www3.epa.gov/pesticides/chem search/reg actions/registration/fs PC-076416 1-Oct98.pdf 5 pp. (10 January 2017). 